2017-11-24

\title{
Interpretations of Child Centred Practice in Early Childhood Education and Care
}

Campbell-Barr, Verity

http://hdl.handle.net/10026.1/10242

10.1080/03057925.2017.1401452

Compare: A Journal of Comparative and International Education

Taylor \& Francis (Routledge)

All content in PEARL is protected by copyright law. Author manuscripts are made available in accordance with publisher policies. Please cite only the published version using the details provided on the item record or document. In the absence of an open licence (e.g. Creative Commons), permissions for further reuse of content should be sought from the publisher or author. 
"This is the author's accepted manuscript. The final published version of this work (the version of record) is published by Taylor and Francis in Compare: A Journal of Comparative and International Education available at: http://dx.doi.org/10.1080/03057925.2017.1401452. This work is made available online in accordance with the publisher's policies. Please refer to any applicable terms of use of the publisher."

[Figure One: Knowledge, Skills and Attitudes for ECEC]

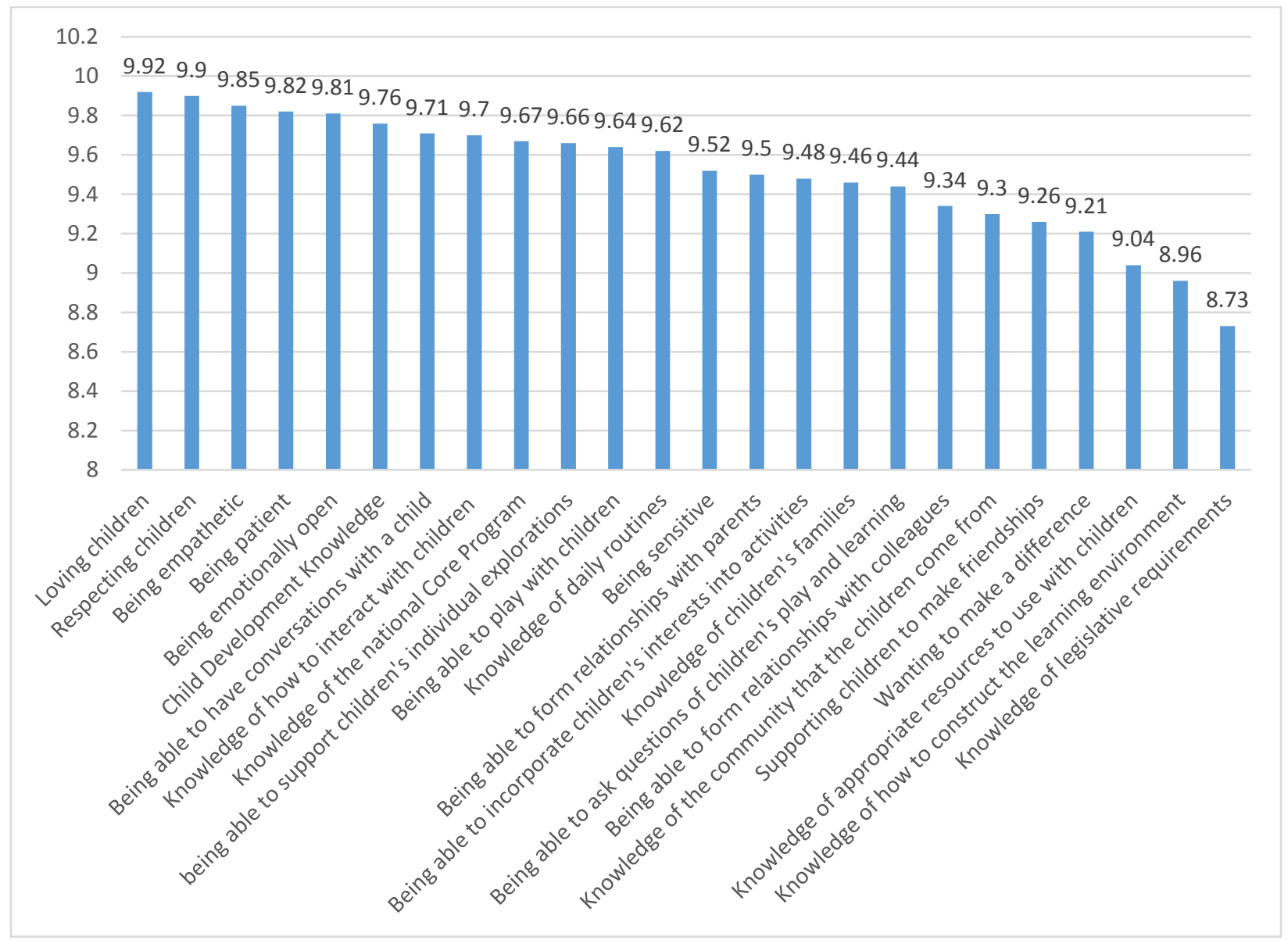

